(C) О.Л. Фучко, Я.І. Сливка, 2020

УДК 616.441-007.61:616.366-002:612.131.17]-055.2

\title{
Функціональний стан центральної та інтракардіальної гемодинаміки у жінок із гіперплазією щитоподібної залози та безкалькульозним холециститом
}

\author{
О.Л. Фучко, Я.І. Сливка \\ ДВНЗ «Ужгородський національний університет», медичний факультет, кафедра фізіології \\ та патофізіології, Ужгород
}

\section{Реферат}

Вступ. Механізми впливу тиреоїдних гормонів на серцево-судинну систему є багатофакторними. Головними вважаються такі: вплив тиреоїдних гормонів на рівні геному; негеномний прямий вплив тиреоїдних гормонів на міокард, який включає дію на мембрани, саркоплозматичний ретикулум, мітохондрії; вплив тиреоїдних гормонів на периферичну циркуляцію.

Мета дослідження: проаналізувати функціональний стан центральної та інтракардіальної гемодинаміки у жінок 3 гіперплазією щитоподібної залози та безкалькульозним холециститом. Об'єкт дослідження - гемодинамічний статус організму жінки з ГЩЗ та безкалькульозним холециститом. Предмет дослідження: зміни гемодинамічного статусу організму жінки з ГЩЗ та безкалькульозним холециститом.

Матеріали та методи: загальноклінічні, стандартні лабораторні методи обстеження, спеціальні клініколабораторні методи: фізіологічні, біохімічні, статистичні.

Параметри центральної та інтракардіальної гемодинаміки реєстрували в стані спокою методом двомірної ехокардіографії в М-режимі ехокамерою «Тоshiba-140» (Японія).

Результати досліджень та їх обговорення. Динаміка змін показників центральної та інтракардіальної геодинаміки вказує на різні, паралельно існуючі шляхи вторинних порушень з боку серцево-судинної системи. Так, значне збільшення ЗПОС, пов'язане зі зниженням еластичності (підвищенням жорсткості судинної стінки) артерій, є елементом концентричного типу гіпертрофії лівого шлуночка. Зростання поштовхового об'єму за відсутності вазоспастичних реакцій та підвищенні венозного тонусу є елементом ексцентричної гіпертрофії.

Висновки. На підставі отриманих даних можна також говорити про наявність у пацієнтів систолічної дисфункції, яка, однак, має переважно функціональний характер.

Виявлені специфічні зміни гомеостатичних характеристик в організмі жінок з гіперплазією щитоподібної залози та безкалькульозним холециститом вимагають розробки нових, більш ефективних (бажано немедикаментозних, зважаючи на патологію печінки і порушення, внаслідок цього ії детоксикаційної здатності) підходів до лікування таких хворих.

Ключові слова: гіперплазія щитоподібної залози, безкалькульозний холецистит, гіпотериоз, серцево-судинна система, гемодинаміка серця.

\author{
The functional state of Central and intracardial hemodynamics in women with thyroid hyperplasia \\ and bezkalkuloznym cholecystitis \\ O.L. Fuchko, Ya.I. Slyvka \\ SHEI "Uzhhorod National University"; Medical faculty; Department of Physiology and Pathophysiology, Uzhhorod
}

Abstract
Introduction The mechanisms of thyroid hormones influence on the cardiovascular system are multifactorial. The following are considered to be the main ones: the influence of thyroid hormones at the genome level; nongenomic direct effect of thyroid hormones on the myocardium, which includes the effect on plasma membrane, sarcoplasmic reticulum, mitochondria; the influence of thyroid hormones on peripheral circulation.

Aim.The robots of the fibula of the concrete of the function will become the central one of the "intracardial hemodynamki" at the girl with the thyroid syllosi tha the ccalculous cholecystitis. It is a hemodynam status of the organ of the gsh to the no-cellulyce. The subject of the dose: the serpent in the hemodynam's status as an organ of the city of GSH is a non-calculous cholecystit.

Materials and methods of research: general clinical, standard laboratory methods of examination, special clinical and laboratory methods: physiological, biochemical, statistical.

Parameters of central and intracardiachaemodynamics have been recorded by the method of resting-state twodimensional M-mode echocardiography in the echo chamber "Toshiba-140" (Japan).

Results and discussio: dynamics of changes of indices of central and intracardial Geodynamics indicates different parallel existing ways of secondary disturbances on the part of cardiovascular system. Thus, a significant increase in ZREF associated with a decrease in elasticity (increased vascular rigidity) of the artery is an element of a concentric drawing type of left ventricular hypertrophy. The increase in volume in the absence of vasospaistic reactions and increasing venous tone is an element of eccentric hypertrophy. ).

Results. On the basis of the data that have been obtained, one may speak of the presence of systolic dysfunction in patients, which, however, is predominantly of functional character.

The revealed specific changes of the homeostatic characteristics in the women's body with thyroid hyperplasia and acalculouscholecystitis require the development of new, more effective approaches(preferably drugfree, taking into account the pathology of the liver and impairment, due to this its hepatic detoxification capacity) to medical treatment of such patients.

Key words: thyroid hyperplasia, acalculouscholecystitis, hypothyroidism, cardiovascular system, cardiac haemodynamics. 
Вступ. Механізми впливу тиреоїдних гормонів на серцево-судинну систему $є$ багатофакторними. Головними вважаються такі: вплив тиреоїдних гормонів на рівні геному; негеномний прямий вплив тиреоїдних гормонів на міокард, який включає дію на мембрани, саркоплозматичний ретикулум, мітохондрії; вплив тиреоїдних гормонів на периферичну циркуляцію [1].

Дія $\mathrm{T}_{3}$ та $\mathrm{T}_{4}$ на кардіоміоцити реалізується на рівні ядер та позаядерних утворень. $\mathrm{T}_{3}$ справляє пряму дію на рівень транскрипції генів, що спостерігається зі змінами вмісту РНК та синтезу протеїнів. Як зауважують Danzi S., Fazio S., саме $\mathrm{T}_{3}$ справляє прямий ядерно-опосередкований ефект на серце [2, 3].

На противагу геномним ефектам тиреоїдних гормонів на серце існують і неядерні ефекти, а саме: на серцевий м'яз, зокрема на мембрани, саркоплозматичний ретикулум і мітохондрії. Ефекти на мембрану включають підвищення активності синоатриального провідника ритму і транспорта глюкози, $\mathrm{Na}$ та Са. Зокрема на внутрішньому боці мембран кардіоміоцитів ідентифіковані рецептори для тиреоїдних гормонів на участках-активаторах для Са-АТФази саркоплазматичного ретикулума, Na-K-АТФази, що є важливими для регуляції роботи серця вважають Туруколов Я., Петунина Н., Yukio H. [4,5].

Завдяки таким ефектам у хворих 3 гіпотиреозом, як правило, Знижується хвилинний об' $€$, підвищується загальний периферичний судинний опір (ЗПСО) у великому колі кровообігу, діастолічний АТ підвищується, що призводить до зменшення пульсового тиску. Зменшується також споживання міокардом кисню.

На думку дослідників Бульби А.Я., Гучко Б.Я., Бариляк Л.Г., Duntas L., порушення метаболізму ліпідів, який $є$ безпосередньо пов'язаним з метаболізмом тиреоїдних гормонів вважається також прямою причиною змін функціонального стану серцево-судинної системи [6,7].

Хоча гіпотиреоз був визначений фактором ризику атеросклерозу та захворювань серцево-судинної системи ще в 1938 році C. Smyth та A. Arbor, тривалий час, особливо у вітчизняній медицині, цьому його аспекту не надавалося відповідної уваги. Обумовлено таке ставлення тим, що, за спостереженнями деяких дослідників, ступінь ризику виникнення інфаркту міокарда при гіпотиреозі не був настільки високим, як можна було б очікувати, виходячи 3 виразності дисліпідемії та атеросклерозу. Пояснювали це тим, що негативний вплив гіпотиреозу на ліпідний обмін частково компенсується зниженою потребою міокарда в кисні. Однак слід зазначити, що аналізували результати досліджень переважно пацієнтів із вже діагностованим гіпотиреозом, у більшості випадків - на фоні проведення замісної терапії. Аналіз дослідження тиреоїдної функції в пацієнтів кардіологічного профілю, зокрема 3 інфарктом міокарда, у вітчизняній літера- турі практично відсутній. А лише такий аналіз може об'єктивізувати значення гіпотиреозу як фактора атеросклерозу та його ускладнень. За даними B.C. Tanis et al., серед пацієнтів 3 перенесеним інфарктом міокарда та дисліпідемією підвищений рівень ТТГ визначали у $27 \%$ жінок віком понад 60 років та у $6,7 \%$ чоловіків віком до 50 років $[6,8,9]$.

Отже, роль гіпотиреозу, у тому числі субклінічного, в розвитку захворювань серцево-судинної системи після оприлюднення результатів Роттердамського дослідження ніхто не піддає сумніву. Такий ризик при гіпотиреозі зростає не лише внаслідок дисліпідемії та гіпертензії, але і внаслідок відхилень у мікроциркуляції та коагуляційному гомеостазі. У пацієнтів з гіпотиреозом, у тому числі субклінічним, спостерігають гіперкоагуляцію та підвищення тромбоцитарної активності крові, вірогідно зростає концентрація VII фактора згортання. Зростає також рівень гомоцистеїну, ще одного важливого маркера розвитку атеросклерозу.

У міокарді при гіпотиреозі відбувається значний набряк м'язових волокон та інтерстиціальної тканини. Ці зміни мають дифузний характер, при тривалому перебігу гіпотиреозу виникає осередковий, а потім дифузний фіброз. При об'єктивному дослідженні виявляється збільшення розмірів серця, розширення його меж. Збільшення розмірів серця, набряк кардіоміоцитів та фіброзні зміни обумовлюють порушення передсердно-шлуночкової провідності.

Метою дослідження було проаналізувати функціональний стан центральної та інтракардіальної гемодинаміки у жінок з гіперплазією щитоподібної залози та безкалькульозним холециститом.

Матеріали та методи. Для вирішення поставлених завдань було відібрано 87 жінок віком 22-54 років, у яких хронічний безкалькульозний холецистит виступав у якості основного діагнозу, а гіперплазія щитоподібної залози була встановлена в ході обстеження. Контрольну групу, рондомізовану за віком, склали 20 здорових жінок. Параметри центральної та інтракардіальної гемодинаміки реєстрували в стані спокою методом двомірної ехокардіографії в М-режимі ехокамерою «Toshiba140» (Японія).

При аналізі отриманих результатів із метою порівняння використовувалися величини, визначені нами при обстеженні контрольної групи жінок.

Статистична обробка отриманих даних проведена методами варіаційної статистики 3 вирахуванням середньої арифметичної, іiі середньої похибки, коефіцієнта кореляції, а також критерію достовірності Стьюдента за допомогою програмного забезпечення Microsoft Excel 2003. Відмінності вважались вірогідними при $\mathrm{p}<0,05$.

Результати досліджень та їх обговорення. У обстежених нами жінок з гіперплазію щитоподібної залози та безкалькульозним холециститом було виявлено певні особливості центральної та інтракардіальної гемодинаміки (табл.1). 
Центральна та інтракардіальна гемодинаміка у жінок із гіперплазією щитоподібної залози та безкалькульозним холециститом $(\mathrm{M} \pm \mathrm{m})$

\begin{tabular}{|c|c|c|}
\hline Показники & Контрольна група & Група хворих \\
\hline ЧСС, уд/хв. & $67,5 \pm 3,8$ & $98,3 \pm 2,4^{*}$ \\
\hline АТ сист., мм рт.ст. & $120 \pm 5$ & $121 \pm 2$ \\
\hline АТ діаст., мм рт.ст. & $80 \pm 4$ & $78 \pm 2$ \\
\hline Серцевий викид, л/хв. & $5,00 \pm 0,30$ & $4,92 \pm 0,22$ \\
\hline ЗПСО, кПа.с/м² & $14,5 \pm 0,5$ & $16,2 \pm 0,8^{*}$ \\
\hline Тривалість серцевого циклу, мс & $950 \pm 21$ & $893 \pm 30^{*}$ \\
\hline Час вигнання, мс & $305 \pm 9$ & $283 \pm 5 *$ \\
\hline $\begin{array}{l}\text { Кінцеводіастолічний об’єм } \\
\text { (КДО), мл }\end{array}$ & $97,5 \pm 2,4$ & $125,1 \pm 3,0^{*}$ \\
\hline Індекс КДО, мл/м² & $64,0 \pm 1,9$ & $69,0 \pm 1,6^{*}$ \\
\hline $\begin{array}{l}\text { Кінцевосистолічний об’єм (КСО), } \\
\text { мл }\end{array}$ & $45,1 \pm 3,0$ & $53,1 \pm 2,9 *$ \\
\hline Індекс КСО, мл/м² & $23,5 \pm 2,2$ & $28,9 \pm 1,2 *$ \\
\hline Поштовховий об’єм, мл & $61,2 \pm 2,4$ & $72,0 \pm 2,7^{*}$ \\
\hline Поштовховий індекс, мл/м² & $33,0 \pm 2,8$ & $40,1 \pm 1,3^{*}$ \\
\hline $\begin{array}{l}\text { Індекс скоротливої активності, } \\
\text { кПа/с }\end{array}$ & $21,2 \pm 0,7$ & $24,8 \pm 0,9 *$ \\
\hline
\end{tabular}

Примітка: * - різниця достовірна з показниками контрольної групи $(\mathrm{p}<0,05)$.

Контрольна група жінок (табл.2).

Таблиця 2

Віковий склад груп обстежених жінок

\begin{tabular}{|l|c|c|}
\hline \multirow{2}{*}{ Групи обстежених } & \multicolumn{2}{|c|}{ Кількість обстежених } \\
\cline { 2 - 3 } & абс. & $\%$ \\
\hline Контрольна $(\mathrm{n}=20):$ & 4 & 20,0 \\
22-30 років & 10 & 50,0 \\
31-40 років & 6 & 30,0 \\
41-54 роки & & \\
\hline Хворі з гіперплазією щитоподібної & 18 & 21,0 \\
залози (n=87): & 43 & 49,0 \\
22-30 років & 26 & 30,0 \\
31-40 років & & \\
41-54 роки & & \\
\hline
\end{tabular}

Відповідно до механізму впливу тиреоїдних гормонів на функцію серцево-судинної системи, у хворих спостерігали зростання частоти серцевих скорочень (на 45,6\%), що призводило до зменшення тривалості серцевого циклу та часу вигнання. Відбувалося достовірне $(\mathrm{p}<0,05)$ зростання (в середньому на $11,7 \%$ ) загального периферичного судинного опору, яке імовірно було пов'язано, з одного боку, з неядерними ефектами тиреоїдних гормонів, 3 іншого - 3 порушеннями метаболізму ліпідів, обумовленими зсувами в метаболізмі тиреоїдних гормонів. При цьому простежувалося зростання поштовхового об'єму (на 17,6\%) та поштовхового індексу (на $21,5 \%$ ), яке до певної міри (при зрослих величинах ЗПСО) забезпечувалося деяким зростанням індексу скоротливої активності (на 17,5\%).

Далі слід проаналізувати дані, отримані щодо кінцеводіастолічного та кінцевосистолічного об’ємів та відповідних індексів. Вказані показники у хворих з гіперплазією щитоподібної залози та безкалькульозним холециститом зростали більшою або меншою мірою: КДО - на 28,3\%, КСО на $17,7 \%$, індексу КДО - на 7,8\%, індексу КСО на $23,0 \%$.

Така динаміка змін досліджуваних параметрів свідчить про наявність у обстежуваних хворих систолічної дисфункції - коли до збільшеного КСО додається звичайна кількість крові, що притікає 3 легеневих вен, збільшується діастолічний об'єм камери, і кінцеві діастолічний тиск та об'єм перевищують норму.

Незважаючи на те, що таке збільшення переднавантаження через механізм Франка-Старлінга призводить до збільшення поштовхового об'єму, через зміни скоротливості кінцевий систолічний об'єм залишається збільшеним. Теоретично, цей 
компенсаторний механізм спрямований на підтримання величини поштовхового об'єму при дисфункції, зумовленій зниженням еластичності серцевого м'яза, зумовленим при досліджуваній патології, значною мірою, неядерним ефектам тиреоїдних гормонів.

Динаміка змін показників центральної та інтракардіальної геодинаміки вказує на різні, паралельно існуючі шляхи вторинних порушень 3 боку серцевосудинної системи. Так, значне збільшення ЗПОС, пов'язане зі зниженням еластичності (підвищенням жорсткості судинної стінки) артерій, є елементом концентричного типу гіпертрофії лівого шлуночка. Зростання поштовхового об'єму за відсутності вазоспастичних реакцій та підвищенні венозного тонусу є елементом ексцентричної гіпертрофії.

Слід підкреслити, що відзначені зміни з боку серцево-судинної системи у обстежених жінок 3 гіперплазією щитоподібної залози та безкалькульо- зним холециститом мають переважно функціональний характер (збільшення ЧСС, посилення скоротливої активності міокарда тощо), свідченням чого є відсутність достовірних змін у них артеріального тиску, оскільки при прогресуванні патологічного процесу відбувається стабілізація АД на високому рівні.

Висновки. На підставі отриманих даних можна також говорити про наявність у пацієнтів систолічної дисфункції, яка, однак, має переважно функціональний характер.

Виявлені специфічні зміни гомеостатичних характеристик в організмі жінок з гіперплазією щитоподібної залози та безкалькульозним холециститом вимагають розробки нових, більш ефективних (бажано немедикаментозних, зважаючи на патологію печінки і порушення, завдяки цьому іï детоксикаційної здатності) підходів до лікування таких хворих.

Інформація про конфлікт інтересів. Автори заявляють про відсутність конфлікту інтересів.

Інформація про фінансування. Автори не отримували ніяких винагород ні в якій формі від фірмвиробників лікарських препаратів, медичного обладнання та матеріалів, у тому числі конкурентів, здатних вплинути на результати роботи.

Особистий внесок кожного автора у виконання роботи:

Фучко О. Л. - збір й обробка матеріалів, написання тексту.

Сливка Я. І. - аналіз отриманих даних, статистична обробка матеріалів.

\section{Список використаної літератури}

1. Ametov A. S., Konyeva M. Yu., Lukanova i. V. Cardio-vessel system at Tireotoksikoze. Consiliummedicum. 2003; 5 (11): 651 - 654.[ in Russian].

2. Danzi S. Thyroid hormone and the cardiovascular system: Minerva Endocrinol. 2004; 29 (3): $139-150$.

3. Fazio S. Effects of thyroid hormone on the cardiovascular system: Recent. Prog. Horm. Res. $2004 ; 59$ (1): 31 -50 .

4. Petunina N. Cardio-Supopovye Oslozhneniya Hyporezoza: Doctor. 2007; 4: 2 - 5. [in Russian].

5. Yukio N. [et al.] Rapid nongenomic actions of thyroid hormone: Proc. Nat. Acad. Sci. USA. $2006 ; 103$ (3 8): $14104-14109$.

6. Bulba A. ya., Guchko b. Ya., Baryliak L. Relationship between the parameters of lipid and endocrine statuses in women with thyroid hyperplasia, arriving at the Truskavets resort: Truskavetskyi balneological Almanac. 2007; 2:149 - 174.. [in Ukraina ].

7. Duntas L. H. Thyroid diseaseand lipids: Thyroid. 2002.; 12 (2): 287 - 293.

8. Izmozherova N. In [the Dr.] frequency of thyroid dysfunction and cardio-vascular pathology in the gimbonite in the sphenoid periode: Problems of the endoscolologist. 2007; 53 (1): 36 - 40. [in Russian].

9. Cappola A.R.,Fried L.P.,ArnoldA. M. Thyroid status, cardiovascular risk, and mortality in older adults. JAMA. 2006; 295( 9.): 1033-1041.

Стаття надійшла до редакції: 27.10.2020 p. 